\title{
ウィンドファームの最適な制御による発電出カの向上とその他の可能性 Optimal Control of Wind Farm Energy Extraction and Beyond
}

\author{
ゴイトジェイプラカス*
}

Jay Prakash GOIT

\section{1.はじめに}

近年，温室効果ガス(CO2 等)の排出を抑制し，化石燃 料への依存を低減するため, 風力などの新エネルギーの 導入が世界的に増加している。 Global Wind Energy Council (GWEC) の年次報告書 ${ }^{1)}$ によると，世界全体で設置され た風力エネルギーの容量は2016年の時点で $486 \mathrm{GW}$ にな っており, 2001 年の $23.9 \mathrm{GW}$ をはるかに上回っている(図 1 を参照)。また, 多数の風力発電タービンを一ヶ所に設 置し, 集中的に発電する陸上・洋上ウィンドファームが 増加している。世界最大の洋上風力発電所はイギリスの London Array ウィンドファームで, 175 基の風車により 630MW の発電能力をもつ。日本国内で最大のウィンドフ アームは青山高原風力発電所で, 60 基の風車によい 95 MW の発電能力をもつ。一方，このような大型ウィンド ファームでは, 風車間のウェークの相互作用により発電
出力が低下し，単独の風車に比べて出力が $40 \%$ まで低く なるケースもある2)。従って, ウェークの相互作用を考慮 し, ウィンドファーム全体の発電出力を向上させるファ 一ム制御に関する研究が注目を浴びている。これは, 風 力の発電価格（COE: Cost of Energy）の低減にも繋がる。

本解説では, 商用風車に使用される制御法を紹介し, ウィンドファーム制御に関する様々なアプローチのレビ ューを行う。その後, ウィンドファームの数值シミュレ ーションと勾配法による最適な制御との連結について説 明する, また, 最適な制御による発電出力の向上効果や, 本手法の他の応用について考察を行う。なお，風力発電 タービンの空気力学 ${ }^{3} や$ や ウィンドファーム内のウェーク の相互作用や乱流構造 ${ }^{4)}$ に関しては, 既に解説論文が存 在するため, 本稿では紹介しない。

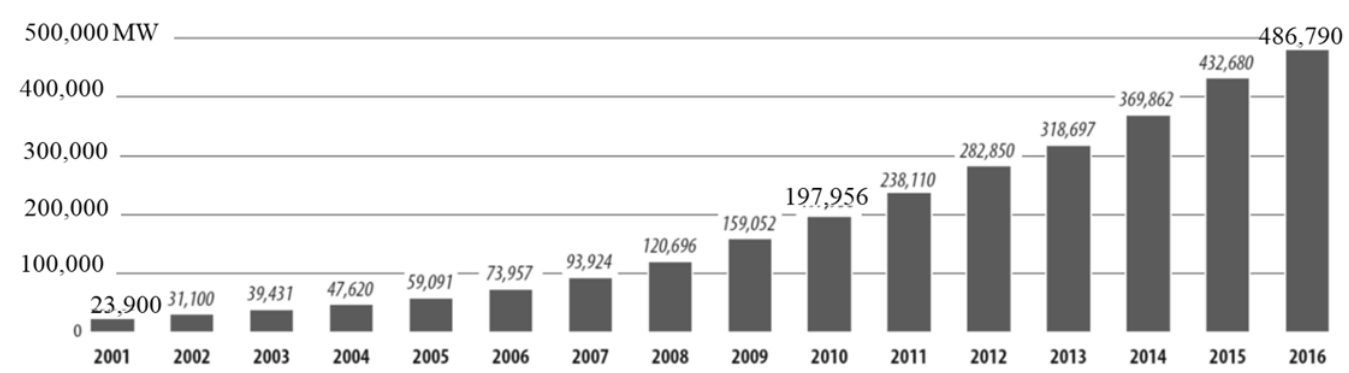

Fig. 1 Global cumulative installed wind energy capacity from 2001 to 2016 . Figure adapted from GWEC: Global Wind Report $2016^{1)}$.

\footnotetext{
* 東京大学大学院工学系研究科 社会基盤学専攻 特任助教

Project Assistant Professor, Department of Civil Engineering, The University of Tokyo
} 
2. 風車及びウィンドファームの制御

\section{1 風車の制御法}

大型水平軸風車 (数百キロワット〜数メガワット) に は主に3つの制御システムがあり，それぞれ：(i) ヨー制 御，(ii) ジェネレータトルク制御，(iii) ブレードピッチ制 御である。ヨー制御では風車ロータの向きを風向に追従 させることにより，発電出力を最大にする。ジェネレー タトルク制御は一般的に可変速風車に使用される制御又 カニズムであり, 風車ロータに作用する空力トルクとジ ェネレータのトルクの差を用いて風車の回転数を制御す る。例えば，風速が定格風速より低いときは，ジェネレ ータトルクの変動によりロータの回転を加速または減速 し，流入風速に対して最適な回転になるよう制御する。 風速が定格風速より高い場合は, ジェネレータトルクを 一定に保つようにする。最後に，ブレードピッチ制御で は名前のとおり, 風車ブレードのピッチ角を変更するこ とにより発電出力を制御する。ブレードピッチ制御は共 同ピッチ制御 (CPC: Collective Pitch Control) と独立ピッチ 制御 (IPC: Individual Pitch Control) の二通りが存在する。 CPC では全てのブレードを同じピッチ角になるように調 節する。これに対して，IPC は個々のブレードのピッチ 角を独立に調節する。後者のほうは動的荷重の低減に大 きく貢献すると言われている5 。しかし，現時点では IPC によるピッチ制御の効果は明確になっていない。なお,

風速の変動に対してピッチ制御の応答が速いことが重要 であり，一般には $8 \%$ sec の最大ピッチ速度が用いられ ている。

図 2 (a) に示すように, 風速や風車の設計仕様により, 水平軸風車の運転状況は 3 つの領域 (Region) に分けら れる。風速がカットイン風速より低いとき, 風のエネル ギーは低いため, 風車は発電せず, 待機状態にいる。こ れを Region 1 と呼ぶ。

Region 2 はカットイン風速から定格風速までの領域で ある。Region 2 では風車が最大効率で運転することが望 ましい。ジェネレータトルク制御により，流入風速に対 しロータの回転を調節する。その結果, 最適な周速比 $(\lambda)$ が得られ, 最大空力効率が保たれる。周速比は次式のよ うに定義される。

$$
\lambda=\frac{\Omega R}{U}
$$

ここで， $\Omega$ は角速度， $\mathrm{R}$ はロータ半径， $U$ は流入風速で ある。Region 2 ではアクティブピッチ制御は必要ではな いが, パワー係数 $\left(C_{P}\right)$ が最大となるよう最適なブレード ピッチ角に設定する。図 2(b) にピッチ角, $\lambda$ と $C_{P}$ の
関係の一例を示す。また, $C_{P}$ は次式のように定義される。

$$
C_{P}=\frac{P}{\frac{1}{2} \rho A U^{3}}
$$

ここて, $P$ は風車の発電出力, $\rho$ 空気密度, $A$ はロータ 面積である。

風速が定格風速より速く, カットアウト風速より低 い) とき, 風車は Region 3 で運転する。 Region 3 では, 風車の機械や電気部品の設計リミットを超えないよう, 風車のパワーを定格出力に抑える必要がある。そのため, アクティブピッチ制御により空力トルクを低減し，発電 出力を抑制する。また, ロータは定格回転数で回転する。 風速がカットアウト風速より高いときは, 風車を過荷重 や損傷から守るため, 風車を停止する。なお, Region 2 か ら Region 3 へのスムーズな移行を可能にするため, 多く の風車は Region 2.5 制御を使用する。

風車単体の制御の詳細に関しては, 文献 6 ,7) を参照され たい。また, 近年では従来のフィードバック制御の他, ライダー計測を用いたフィードフォワード制御 ${ }^{8)} や$ Predictive 制御 5) の応用も検討されている。

(a)

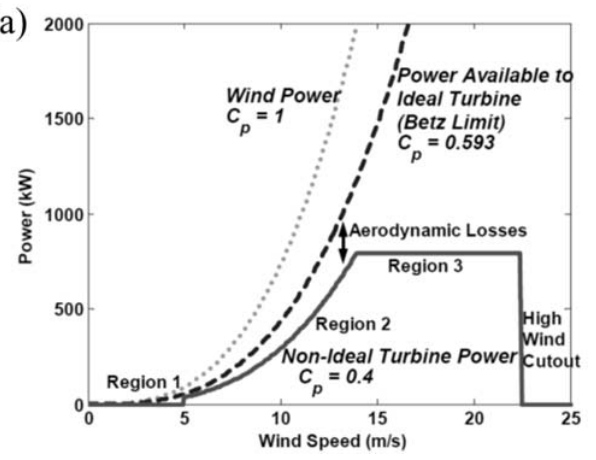

(b)

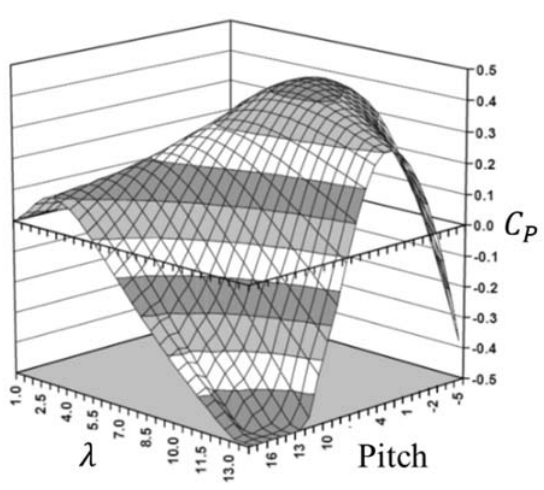

Fig. 2 (a) Steady-state power curve for a horizontal axis wind turbine. (b) An example of a $\boldsymbol{C}_{\boldsymbol{P}}-\boldsymbol{\lambda}$ - pitch surface. Figures adapted from NREL technical report ${ }^{9}$. 


\section{2 ウィンドファームの制御手法}

近年, 風車単体の制御よりもウィンドファーム全体の 制御が多く注目を浴びている。ウィンドファーム制御に 関しては, 発電出力の向上の他, ファーム内の風車の荷 重低減, 発電出力の安定化, グリッドサポートなどを目 的とした研究が進められている 10_12)。ウィンドファーム 制御の初期の研究として, Steinbuch ${ }^{13)}$ らの研究が挙げら れる。彼らの提案では, 流入風に対し上流の風車の発電 出力を低下させることにより, 後流の風速が高く保たれ, 下流の風車の発電出力大きく低下するのを防ぐことが出 来る。これはウィンドファーム全体の発電出力の向上に も繋がる。Horvat ${ }^{14)}$ らはウィンドファーム内の空気力学 をウェークモデルを用いて定義し, Sequential quadratic programming (SQP) を使用した最適化問題を解いた。そし て, Region 2 運転でファーム全体の発電出力を最大化す ることを目的に, 各風車の最適な回転数を求めた。

Soleimanzadeh $^{10)} ら$ はアーム内の風車の荷重低減を目的 として，2 次元 Navier-Stokes 方程式を用いた分散型制御 システムを開発した。

上述のモデル型制御の他に，モデルフリー制御 (model-free control) 方法も提案されている 15_17)。モデル型 制御は簡略化された後流モデルまたは複雑な 3 次元流体 計算のモデルを使用する。前者の場合は, ウィンドファ 一ム内の複雑な流れを再現することが出来ない。また, 後者は計算時間が長い。したがって, 実際の応用を考え ると, モデル型制御に比べてモデルフリー制御の方が適

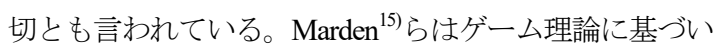
た分散型学習アルゴリズムを提案した。この手法では, 個々の風車を周りの風車の発電出力の情報を使用して制 御する。Gebraad \& van Wingerden ${ }^{17)}$ はデータ駆動制御 (data driven control) を用いてウィンドファーム内の個々 の風車の制御設定の最適化を行った (図 3 を参照)。最適 化手法の収束時間が速いため, 時間的に変化する風速に も適用出来た。本手法では勾配法により風車の制御パラ メータの更新を行った。また，隣接する風車同士の情報 のみを使用している。一方 $\mathrm{Ahmad}^{16)}$ らはウィンドファー ムの発電出力の向上を目的に Multi-resolution simultaneous perturbation stochastic approximation (MR-SPSA) を用いた モデルフリー手法を提案した。この方法は収束時間が速 い上, 他のモデルフリー手法に比べ発電出力の向上効果 も大きい。しかし，この手法について実験や数值計算に よる検証は行われていない。

ウィンドファームの上流側の風車の後流が下流にある 風車に当たらないようにすることによっても, ウィンド
ファーム効率の向上が可能である。後流を偏向させる一 つの方法として, ヨーミスアラインメント（yaw misalignment)が注目を集めている。Fleming ${ }^{18)} ら は$ 後流の 偏向による制御効果を Large-eddy simulation (LES) によっ て確認した。ヨーミスアラインメントの他, 風車チルト 角の制御による後流の上方向または下方向への偏向や, 独立ピッチ制御による後流の偏向がウィンドファームの 発電出力や風車の荷重に与える影響を発表している。後

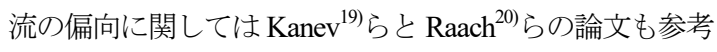
されたい。

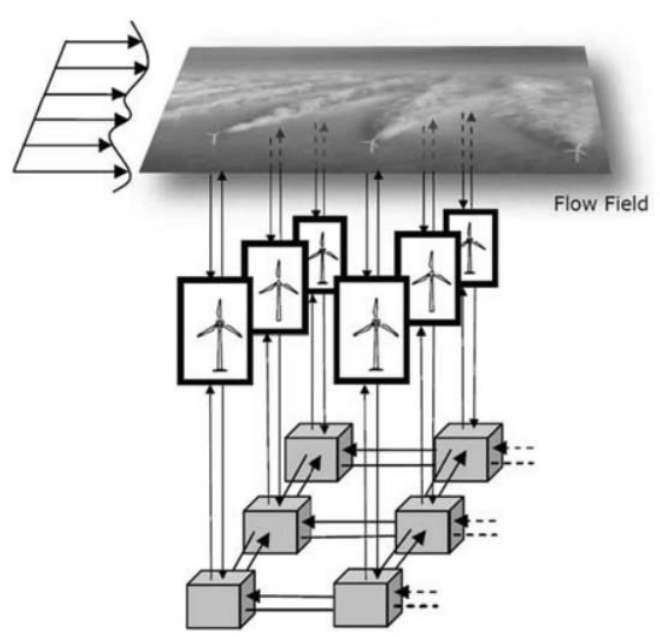

Fig. 3 Schematic of the distributed wind farm control. Figure adapted from Gebraad \& van Windgerden ${ }^{17}$.

3. ウィンドファームのシミュレーションと最適な制御 の連結

ウィンドファーム制御の大きな課題は, ウィンドファー ム内の複雑な乱流と制御の間の相互作用である。近年, ウィンドファームの LES や風洞実験より, ファーム内の 風車と大気境界層 (ABL: Atmospheric Boundary Layer)の 相互作用に関して多くのことがわかってきた ${ }^{21,22)}$ 。しか し， ウィンドファーム内の流れに関する知識をもとに， 直観や経験により制御システムを製作することは難しい と思われる。したがって, 2 章で解説した研究では, 期待 通りの制御効果が得られていない。そこで, Goit \& Meyers ${ }^{23)}$ は Large-eddy simulation (LES) を用いた, 大規模ウィン ドファーム内の流れを考慮したウィンドファームの協調 制御を提案した。勾配法及びアドジョイント法による最 適化手法を流体シミュレーシと連結し，大気境界層内の 乱流とウィンドファームの制御システムの動的相互作用 を考慮した。本章では Goit \& Meyers ${ }^{23)}$ 及び Goit, Munters 
\& Meyers ${ }^{24}$ の研究成果について解説する。

3. 1 ウィンドファームのシミュレーション

ウィンドファームの流体計算には Large-eddy simulation (LES) が使用されるケースが多い。LES の支配方程式は, フィルターされた Navier-Stokes 方程式である。

\section{$\nabla \cdot \widetilde{\boldsymbol{u}}$}

$\frac{\partial \widetilde{\boldsymbol{u}}}{\partial \boldsymbol{t}}+\widetilde{\boldsymbol{u}} \cdot \nabla \widetilde{\boldsymbol{u}}=-\frac{1}{\rho} \widetilde{\boldsymbol{p}}+\nabla \cdot \tau_{M}+\boldsymbol{f}+\lambda(\boldsymbol{x})\left(\widetilde{\boldsymbol{u}}_{\mathrm{in}}-\widetilde{\boldsymbol{u}}\right)$

ここで, $\widetilde{\boldsymbol{u}}=\left[\tilde{u}_{1}, \tilde{u}_{2}, \tilde{u}_{3}\right]$ は風速べクトル, $\tilde{p}$ は圧力, $\boldsymbol{\tau}_{\boldsymbol{M}}$ は サブグリッドスケール(subgrid-scale: SGS)モデルである。図 4 は 計算領域の概略を示す。Goit らは SP-Wind と言うイン八 ウスコードを用いた。SP-Wind では，水平方向は pseudo-spectral 法, 垂直方向は 4 次精度差分法により離散 化がされている。Pseudo-spectral 法による離散化の場合は 周期境界条件になってしまうため, フリンジ法により外 力,すなわち $\lambda(\boldsymbol{x})\left(\widetilde{\boldsymbol{u}}_{\mathrm{in}}-\tilde{u}\right)$ を用いて $\Gamma_{1}^{-}$での流入境界条件を

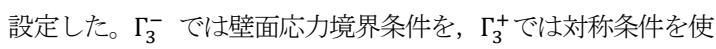
用した。 $\boldsymbol{f}$ は風車が流れに与える力で, 今回は actuator-disk model (ADM) によりモデル化し次式のように定義した。

$f^{i}=\frac{1}{2} C_{T, i}^{\prime} \widehat{V}_{i}^{2} \mathcal{R}_{i}(x) e_{\perp} \quad i=1 \ldots . . N_{t}$

ここで, $\boldsymbol{C}^{\prime}{ }_{T, i}$ はスラスト係数, $\hat{V}_{i}$ は風車ロータ上の平均 風速, $\mathcal{R}_{i}(x)$ はスムージング関数である。 $N_{t}$ は風車の 数で, 今回は 50 台の風車を $10 \times 5$ の格子型に並べたもの を計算対象とした。各風車の直径は $\mathrm{D}=100 \mathrm{~m}$ であり, 風車間距離は流れ方向は $S_{x}=7 D$, スパン方向は $S_{y}=6 D$ とした。

図 5 はウィンドファーム内の瞬間風速を示す。水平面 はハブ高さの風速場を示しており, 風車後流の典型的な ミアンダリングが観察出来る。

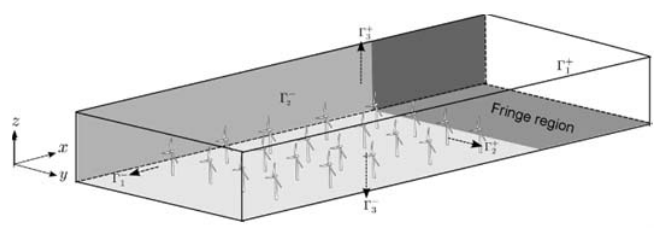

Fig. 4 Computational domain. Figure adapted from Goit, Munters \& Meyers ${ }^{24)}$.

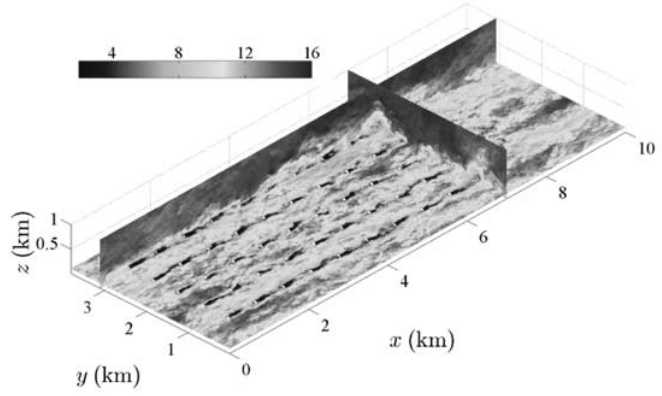

Fig. 5 Snapshot representing instantaneous velocity fields from wind farm simulation. The horizontal plane in the figure is taken at the hub height. Figure adapted from Goit, Munters \& Meyers ${ }^{24)}$.

\section{2 勾配法及びアドジョイント法による最適化}

最適化問題の目的とし, ウィンドファームの発電出力 の向上とした。目的関数は次式で定義した：

$$
\begin{aligned}
& \min _{C_{T, i}^{\prime}(t) ; \widetilde{u}} J=\int_{0}^{T} \sum_{i=1}^{N_{t}}-P_{i} d t \\
& =\int_{0}^{T} \sum_{i=1}^{N_{t}}-\frac{1}{2} C_{T, i}^{\prime}(t) \widehat{V}_{i}{ }^{2} V_{i} d t
\end{aligned}
$$

制御パラメータとして風車のスラスト係数 $C^{\prime}{ }_{T, i}$ を用いた。 個々の風車に対して， $C^{\prime}{ }_{T, i}$ を時間的に変更した。最適化 問題の算出には Polak-Ribiere 共役勾配法 (Conjugate gradient method)とブレント法 (Brent line search alogorithm) を用いた。本手法では目的関数 $\boldsymbol{J}$ の勾配 $\nabla \boldsymbol{J}$ を算出する 必要がある。しかし, 今回の最適化問題の空間時間一状 態空間の自由度は非常に大きいため, 従来の差分法によ る勾配の算出は難しいと考えられる。したがって，勾配 はアドジョイント法 (Adjoint method)により算出した。ア ドジョイントの導出に関しては参考文献 ${ }^{23)}$ を参照された い。ここではアドジョイントLES の式のみを示す。

$$
\begin{gathered}
\nabla \cdot \xi=0 \\
-\frac{\partial \xi}{\partial t}-\widetilde{u} \cdot \nabla \xi-(\nabla \xi)^{T} \cdot \widetilde{u} \\
=-\frac{1}{\rho} \pi+\nabla \cdot \tau_{M}^{*}+f^{*}-\lambda(x) \xi
\end{gathered}
$$

ここで, $(\xi, \pi)$ は $(\widetilde{\boldsymbol{u}}, \tilde{p})$ に対応するアドジョイント変数 である。更に， $\boldsymbol{f}^{*}$ と $\boldsymbol{\tau}_{M}^{*}$ はそれぞれ風車のアドジョイン ト力とアドジョイント SGS である。アドジョイント境界 条件は流れ計算の境界条件と同じである。アドジョイン 卜方程式 (6) は流れ計算の方程式 (3)と似ている。しかし, 時間項と移流項は負であるため, アドジョイント方程式 
は時間と逆方向に計算される上流に移動する。流れ計算 及びアドジョイント計算より目的関数の勾配は次式から 求められる。

$$
\nabla \mathcal{J}=\frac{1}{2} \int_{\Omega} \widehat{V}^{\circ 2} \circ \mathcal{R}(x)\left[(-\widetilde{u}+\xi) \cdot e_{\perp}\right] d x
$$

ここで, ${ }^{\circ}$ は点ごとの Hadamard 積であり， $\widehat{\boldsymbol{V}}^{\circ} \mathbf{2}$ 点ごと の $\hat{V}$ の二乗である。図 6 はアドジョイント速度を示す。 アドジョイント速度は風車の位置から生成し, 上流に移 動していることがわかる。

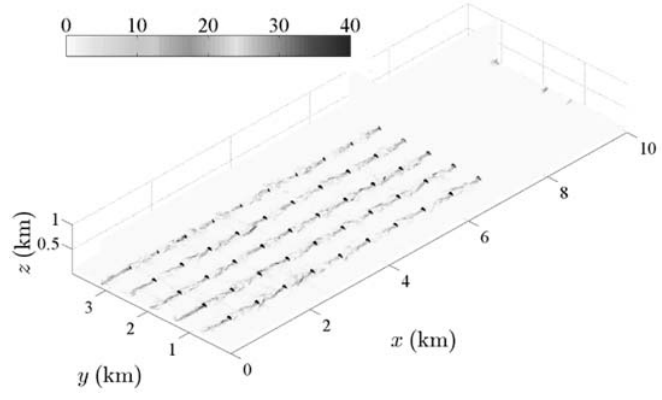

Fig. 6 Contours of instantaneous streamwise adjoint fields. Figure adapted from Goit, Munters \& Meyers ${ }^{24)}$.

\section{3 発電出力の向上への応用}

はじめに, 図 7 はウィンドファーム内の一つの風車の 最適なスラスト係数 $\left(C^{\prime}{ }_{T}\right)$ の時系列を示寸。 $C^{\prime}{ }_{T}$ は今回 の最適化問題の制御パラメータである。ここで制御は乱 流の影響により強く変化していることがわかる。また, ボックス制約の上限と下限 $\left(0 \leq C^{\prime}{ }_{T} \leq 4\right)$ と良く接触 している。しかし, 時系列の一部を拡大して観察すると, $C^{\prime}{ }_{T}$ の変動の周期は早くても約 10 秒ぐらいである。した がって, 実際の風車のブレードピッチやトルク制御を用 いて実現することが可能である。しかし，この最適化は 荷重を考慮してないため, 疲労荷重を大幅に増加すると 思われる。

図 8 はウィンドファーム内の総発電出力の時系列を示 す。図 8(a)は無限に長いウィンドファームの発電出力を, 図 98b)は有限の長さのウィンドファームの発電出力を示 している。図 7 の $C^{\prime}{ }_{T}$ の変動により, 最適な制御の開始 後に発電出力は大きく変動している。両方の場合におい て最適な制御がないときと比べ，最適な制御があるとき では発電出力が向上している。無限に長いウィンドファ 一ムの場合, 発電出力の向上率は $16 \%$ である。これに対 して, 有限の長さのウィンドファームの発電出力の向上
率は 7\%である。後者の場合, 流入風に対して一列目にあ る風車についてはもともと最適な条件で稼働しているた め, 今回の最適な制御による効果は低い。したがって, ウィンドファーム全体の発電出力の向上率は無限に長い ウィンドファームに比べて低い。
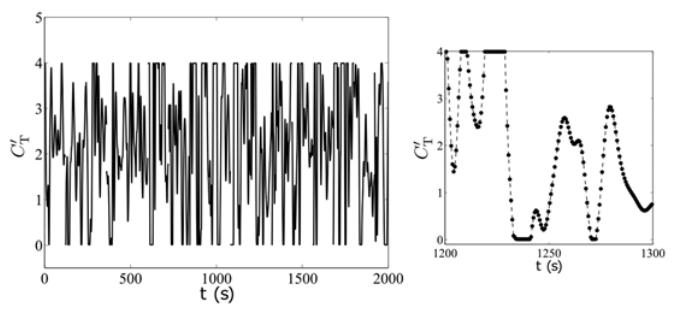

Fig. 7 Time evolution of the thrust coefficient of one of the turbines in the farm ${ }^{24)}$.
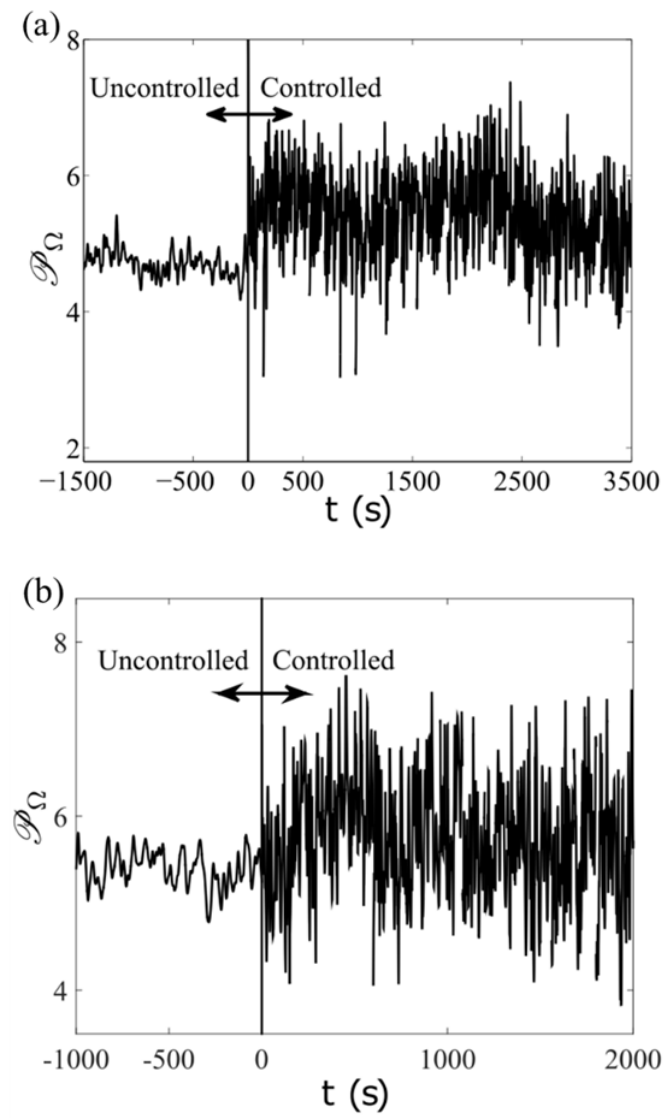

Fig. 8 Time evolution of total farm power. (a) Infinite farm, (b) Finite farm ${ }^{23,24)}$. 


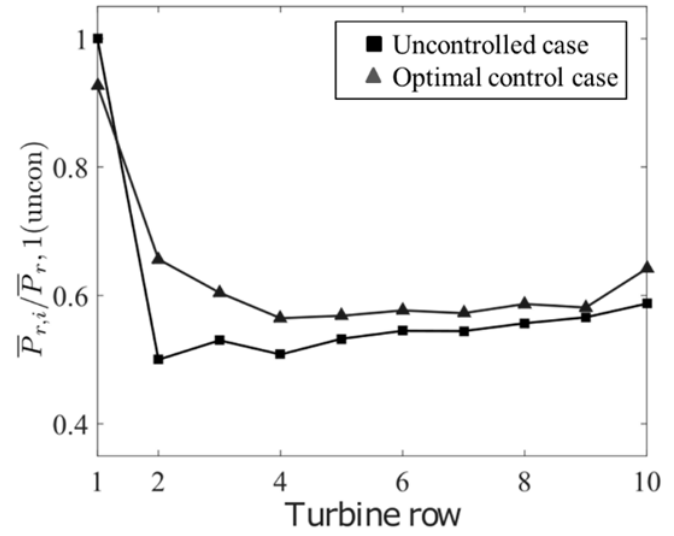

Fig. 9 Comparison of time-averaged power for the controlled and uncontrolled farm as a function of turbine row ${ }^{24)}$

(a)

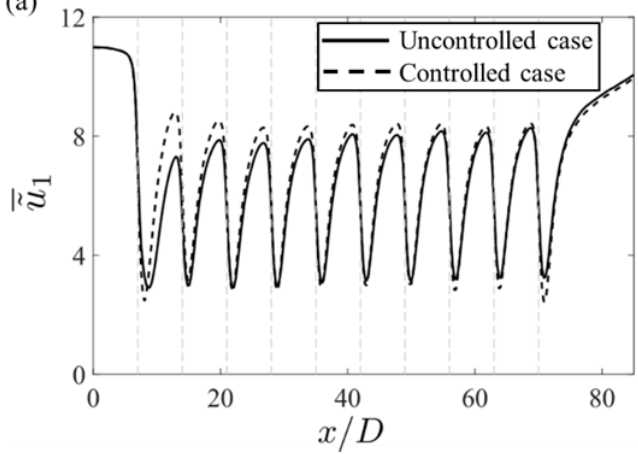

(b)

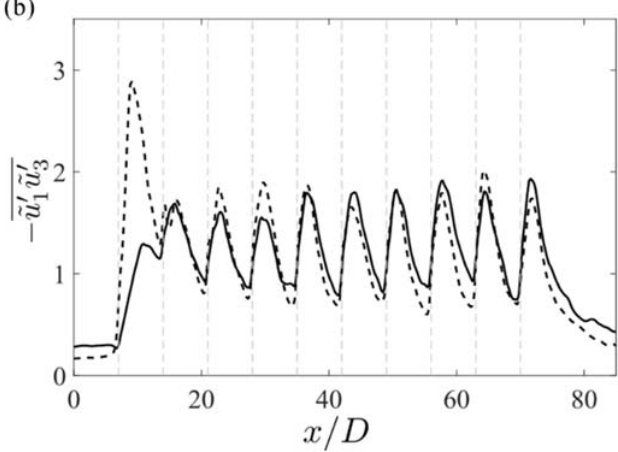

Fig. 10 Time and column averaged profiles of (a) streamwise velocity through the rotor center, (b) Reynolds stress through the turbine tip ${ }^{24)}$.

図 9 は発電出力の時間平均及び横列平均を風車列の関 数として示している。結果は制御なしの場合の横一列目 の平均発電出力で正規化している。制御なしの結果は, 実際のウィンドファームの計測值と同じ傾向を示してい $3^{2)}$ 。横 2 列目で発電出力は急に低下し, それより下流の 横列では発電出力はあまり低下しない。最適な制御を適
用した場合の結果をみると，横一列目の発電出力は少し 低下していることがわかる。一方，下流の列の風車の発 電出力は向上している。また, 発電出力が一定となるま で低下するときの課程は滑らかである。このような出力 分布は最適化によって得られた結果であり, 2 章で解説し た文献では得られていない。

図 10 は平均風速及びレイノルズ忘力の流れ方向の分布 を示している。垂直破線は風車の位置を示す。図 10(a) の ハブ高さでの風速に関しては最適な制御をした場合，後 流の回復が良くなり風車の位置での風速が速いことが観 察できる。図 10(b) は風車最高の位置でのレイノルズ応 力を示している。横一列目に関しては最適な制御をした 場合, レイノルズ応力が増加し, 後流回復に貢献する。 しかし，下流の列に関してはレイノルズ応力はそれほど 増加しない。

\section{4. 結論と今後の展望}

本解説ではウィンドファーム制御の様々な研究を紹介 した。初期ではウィンドファーム内の風車の発電出力を 静的に調節する手法が提案されていたが，近年では制御 パラメータの動的な調節による発電出力向上，風車荷重 の低減に関する研究が進められている。その中で, モデ ル型制御は簡略化された後流モデルや 2 次元, 3 次元流体 計算を使用する。これに対し，モデルフリー手法として は学習アルゴリズムを使用した制御法や，データ駆動制 御が提案されている。

次に，LES を用いたウィンドファーム内の流れを考慮 したウィンドファームの協調制御を紹介した。この研究 では，勾配法及びアドジョイント法による最適化手法を 流体シミュレーシと連結し， ウィンドファーム内の流れ と制御システムの動的相互作用を考慮した。制御の効果 として，ウィンドファームの発電出力は 7\% 16\%まで向 上することが出来た。

計算時間が長く，計算コストも高いため，この最適化 手法を実際に応用することは難しい。しかし，この研究 から得られた知識や経験は，実際に応用可能な制御シス テムの開発に貢献できると思われる。今回は紹介してい ないが，本手法は後流の偏向を目的としたヨーミスアラ インメントの制御 ${ }^{25}$, 発電出力の安定化, グリッドサポ 一トなどにも応用されている。

今後の進展としては，最適化問題に大気境界層の安定 度や複雑地形の効果などを考慮することが考えられる。 また，発電出力に限らず，荷重などを含めた多目的最適 化問題の計算が重要である。 
参考文献

1) Global Wind Report. Global Wind Energy Council (GWEC). (2017)

2) Barthelmie RJ, Rathmann O, Frandsen ST, Hansen KS, Politis ES, Prospathopoulos J et. al. Modelling and measurements of wakes in large wind farms. J Phys Conf Ser. , 75(1), 012049, (2007)

3) Sørensen JN. , Aerodynamic Aspects of Wind Energy Conversion. Annu Rev Fluid Mech., 43, pp.427-48, (2011)

4) Stevens RJ a. M, Meneveau C., Flow Structure and Turbulence in Wind Farms. Annu Rev Fluid Mech., 49(1), pp.311-339, (2016)

5) Navalkar ST, Solingen E Van, Wingerden J Van., Wind Tunnel Testing of Subspace Predictive Repetitive Control for Variable Pitch Wind Turbines. IEEE Trans Control Syst Technol. , 23(6), pp.2101-2116, (2015)

6) Burton T, Sharpe D, Jenkins N, Bossanyi E, Hassan G, Wiley J. Wind Energy Handbook, (2001)

7) Johnson KE, Fingersh LJ, Balas MJ, Pao LY., Methods for increasing region 2 power capture on a variable-speed wind turbine, J Sol Energy Eng. , 126, pp.1092-1100, ( 2004)

8) Scholbrock A, Fleming P, Schlipf D, Wright A, Johnson K, Wang N., Lidar-Enhanced Wind Turbine Control: Past , Present, and Future. ACC.,pp.1399-1406, (2016)

9) Johnson K., Adaptive torque control of variable speed wind turbines, (2004)

10) Soleimanzadeh M, Wisniewski R, Kanev S., An optimization framework for load and power distribution in wind farms, J Wind Eng Ind Aerodyn., 107-108, pp.256262, (2012)

11) Johnson KE, Thomas N., Wind farm control: addressing the aerodynamic interaction among wind turbines, Proceedings of the American Control Conference, pp. 2104-2109, (2009)

12) Siniscalchi-minna S, Bianchi FD, Ocampo-martinez C. Predictive control of wind farms based on lexicographic minimizers for power reserve maximization, American Control Conference (ACC), (2018)

13) Steinbuch M, de Boer WW, Bosgra OH, Peters S, Ploeg J., Optimal control of wind power plants, J Wind Eng Ind Aerodyn., 27, pp.237-246, (1988)
14) Horvat T, Spudic V., Quasi-stationary Optimal Control for Wind Farm with Closely Spaced Turbines. MIPRO, Proceedings of the 35th International Convention IEEE, pp. 829-834, (2012)

15) Marden JR, Ruben SD, Pao LY., A Model-Free Approach toWind Farm Control Using Game Theoretic Methods. Under Submission, p. 1-11, (2012)

16) Ahmad MA, Azuma SI, Sugie T., A model-free approach for maximizing power production of wind farm using multi-resolution Simultaneous Perturbation Stochastic Approximation, Energies, 7, pp.5624-5646,(2014)

17) Gebraad PMO, Wingerden JW van., Maximum power-point tracking control for wind farms, Wind Energy, 18, pp.429-447, (2014)

18) Fleming PA, Gebraad PMO, Lee S, van Wingerden JW, Johnson K, Churchfield M et. al., Evaluating techniques for redirecting turbine wakes using SOWFA, Renew Energy, 70, pp.211-218, (2014)

19) Kanev SK, Savenije FJ, Engels WP., Active wake control: An approach to optimize the lifetime operation of wind farms, Wind Energy, pp.1-14, (2018(October 2016))

20) Raach S, Boersma S, Wingerden JW van, Schlipf D, Cheng PW., Robust lidar-based closed-loop wake redirection for wind farm control. IFAC (International Federation of Automatic Control), pp. 4498-5403, (2017)

21) Calaf M, Parlange MB, Meneveau C., Large eddy simulation study of scalar transport in fully developed wind-turbine array boundary layers, Phys Fluids, 23(12),(2011)

22) Chamorro LP, Porté-Agel F., Turbulent flow inside and above awind farm: A wind-tunnel study, Energies, 4, pp1916-1936, (2011)

23) Goit JP, Meyers J., Optimal control of energy extraction in wind-farm boundary layers, J Fluid Mech. , 768, pp.5$50,(2015)$

24) Goit JP, Munters W, Meyers J., Optimal coordinated control of power extraction in LES of a wind farm with entrance effects, Energies, 9(1), (2016)

25) Munters W, Meyers J., Dynamic Strategies for Yaw and Induction Control of Wind Farms Based on Large-Eddy Simulation and Optimization, Energies, 11(1), 177, (2018) 